\title{
Thermal Comfort and Optimum Humidity Part 1
}

\author{
M. V. Jokl
}

The hydrothermal microclimate is the main component in indoor comfort. The optimum hydrothermal level can be ensured by suitable changes in the sources of heat and water vapor within the building, changes in the environment (the interior of the building) and in the people exposed to the conditions inside the building. A change in the heat source and the source of water vapor involves improving the heat insulating properties and the air permeability of the peripheral walls and especially of the windows. The change in the environment will bring human bodies into balance with the environment. This can be expressed in terms of an optimum or at least an acceptable globe temperature, an adequate proportion of radiant heat within the total amount of heat from the environment (defined by the difference between air and wall temperature), uniform cooling of the human body by the environment, defined a) by the acceptable temperature difference between head and ankles, b) by acceptable temperature variations during a shift (location unchanged), or during movement from one location to another without a change of clothing. Finally, a moisture balance between man and the environment is necessary (defined by acceptable relative air humidity). A change for human beings means a change of clothes which, of course, is limited by social acceptance in summer and by inconvenient heaviness in winter. The principles of optimum heating and cooling, humidification and dehumidification are presented in this paper.

Hydrothermal comfort in an environment depends on heat and humidity flows (heat and water vapors), occurring in a given space in a building interior and affecting the total state of the human organism.

Keywords: thermal comfort, optimum humidity, hygienic standards.

\section{Sources of heat and humidity}

The various sources of heat and water vapor, especially in a cramped space, under the roof etc., can lead to hydrothermal comfort disturbance within an interior, especially if the thermal-insulation properties and ventilation of the building are not on a proper level.

\subsection{Sources of heat and cold}

The outdoor climatic situation is the greatest source of heat and cold for the interior of a building. Heat and cold are transferred indoors through the outer walls of a building. Windows play a major role in this field: they are the greatest source of heat losses in winter and of heat gains in summer.

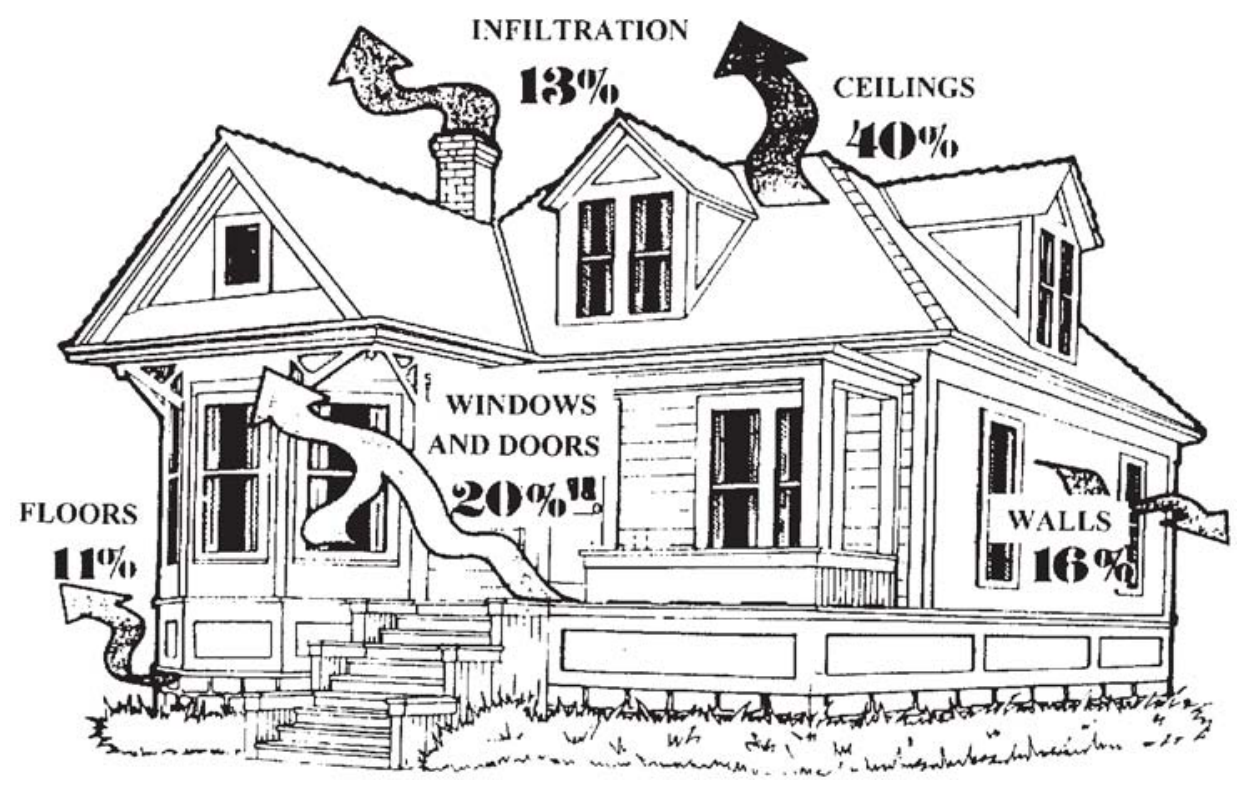

Fig. 1: Heat losses from a family house 
For example, the heat loss from a detached family house is $20 \%$ through the windows, and only $16 \%$ through the walls (Fig. 1), [10], [15]. Thus very great attention should be given to the quality of windows, especially at times when energy prices are rising rapidly. If not, windows will function more or less as holes through which heat escapes from the building. Well insulated windows are also useful in summer: they decrease the heat flow to the interior from outdoors, thus improving the thermal comfort.

It does not matter from thermal point of view whether the windows are made of plastic or of wood. Easy maintenance is the main advantage of plastic windows (no painting is necessary), but their decreased mechanical strength (plastic window frames must be more massive) causes loosenig of the fittings after some time, and their almost perfect air tightness can decrease the natural air exchange in an interior beneath the tolerable limit. Wooden windows (several layers of wood glued together, so called Eurowindows) are now wide- spread in Europe, following the period of plastic windows. Eurowindows do not suffer from deformation and, thanks to the application of synthetic resin for glueing, maintenance is not demanding.

Various human activities, especially cooking and ironing (the input from these appliances contributes to the heat gain in the room) and also people themselves (especially if several people are present in a room) constitute heat sources within a building. Heat (so called basal metabolic heat) is produced by the liver of a person at rest (e.g. asleep) in relationship to age (children generate more heat than adults) and sex (females produce less heat than males, so they need a higher temperature in a room (Fig. 2). Heat production increases with bodily activity, and heat is produced mainly by the muscles (so called net metabolic heat, in the range from 40 to $170 \mathrm{~W} / \mathrm{m}^{2}$ while working at home. Basal metabolic heat must be added to the metabolic heat values, of course) (Table 1).

Table 1: Net metabolic heat, in the course of various typical activities (ASHRAE Fundamentals Handbook, 1985)

\begin{tabular}{|c|c|c|}
\hline \multirow[t]{2}{*}{ Activity } & \multicolumn{2}{|c|}{$\dot{q}_{\mathrm{m}, \text { net }}$} \\
\hline & {$[\mathrm{met}]$} & {$\left[\mathrm{W} \cdot \mathrm{m}^{-2}\right]$} \\
\hline \multicolumn{3}{|l|}{ RESTING } \\
\hline Sleeping & 0 & 0 \\
\hline Recycling & 0.1 & 6 \\
\hline Seated, quiet & 0.3 & 18 \\
\hline Standing, relaxed & 0.5 & 29 \\
\hline \multicolumn{3}{|l|}{ WALKING } \\
\hline \multicolumn{3}{|l|}{ On the level $\mathrm{m} / \mathrm{s}$} \\
\hline 0.89 & 1.3 & 76 \\
\hline 1.34 & 1.9 & 111 \\
\hline 1.79 & 3.1 & 181 \\
\hline \multicolumn{3}{|c|}{ MISCELLANEOUS OCCUPATIONS } \\
\hline $\begin{array}{l}\text { Bakery (e.g., cleaning tins, } \\
\text { packing boxes) }\end{array}$ & 0.7 to 1.3 & 11 to 76 \\
\hline $\begin{array}{l}\text { Brewery (e.g., filling bottles, } \\
\text { loading beer boxes onto a belt) }\end{array}$ & 0.5 to 1.7 & 29 to 99 \\
\hline \multicolumn{3}{|l|}{ Bricklaying } \\
\hline Bricking a wall & 1.8 & 106 \\
\hline \multicolumn{3}{|l|}{ Carpentry } \\
\hline Machine sawing, table & 1.1 to 1.5 & 64 to 87 \\
\hline Sawing by hand & 3.3 to 4.1 & 192 to 239 \\
\hline Planing by hand & 4.9 to 5.7 & 285 to 332 \\
\hline \multicolumn{3}{|l|}{ Foundry Work } \\
\hline Using a pneumatic hammer & 2.3 to 2.7 & 134 to 157 \\
\hline Tending furnaces & 4.3 to 6.3 & 250 to 367 \\
\hline
\end{tabular}

\begin{tabular}{|c|c|c|}
\hline \multirow[t]{2}{*}{ Activity } & \multicolumn{2}{|c|}{$\dot{q}_{\mathrm{m} \text {, net }}$} \\
\hline & [met] & {$\left[\mathrm{W} \cdot \mathrm{m}^{-2}\right]$} \\
\hline $\begin{array}{l}\text { Garage Work (e.g., replacing } \\
\text { tires, raising cars by jack) }\end{array}$ & 1.5 to 2.3 & 87 to 134 \\
\hline General Laboratory Work & 0.7 to 1.1 & 41 to 64 \\
\hline \multicolumn{3}{|l|}{ Machine Work } \\
\hline Light (e.g., electrical industry) & 1.3 to 1.7 & 76 to 99 \\
\hline Heavy (e.g., steel work) & 2.8 to 3.8 & 163 to 221 \\
\hline Shop Assistant & 1.3 & 76 \\
\hline Teacher & 0.9 & 52 \\
\hline Lecture in a large hall & 0.8 to 2.2 & 46 to 129 \\
\hline Watch repairer, seated & 0.4 & 23 \\
\hline \multicolumn{3}{|l|}{ Vehicle driving } \\
\hline Car in highway & 0.7 & 39 \\
\hline $\begin{array}{l}\text { Car in city-center (busy } \\
\text { period) }\end{array}$ & 2.1 & 124 \\
\hline Car (average) & 0.8 & 47 \\
\hline Motorcycle & 1.3 & 76 \\
\hline Heavy vehicle & 2.5 & 146 \\
\hline Aircraft flying routine & 0.7 & 41 \\
\hline Instrument landing & 1.1 & 64 \\
\hline Combat flying & 1.7 & 99 \\
\hline $\begin{array}{l}\text { Maximal physical output } \\
\text { (short-term) }\end{array}$ & 16.9 & 982 \\
\hline \multicolumn{3}{|l|}{ DOMESTIC WORK } \\
\hline House cleaning & 1.3 to 2.7 & 76 to 157 \\
\hline Cooking & 0.9 to 1.3 & 52 to 76 \\
\hline
\end{tabular}




\begin{tabular}{|c|c|c|c|c|c|}
\hline \multirow[t]{2}{*}{ Activity } & \multicolumn{2}{|c|}{$\dot{q}_{\mathrm{m}, \text { net }}$} & \multirow[t]{2}{*}{ Activity } & \multicolumn{2}{|c|}{$\dot{q}_{\mathrm{m}, \text { net }}$} \\
\hline & [met] & {$\left[\mathrm{W} \cdot \mathrm{m}^{-2}\right]$} & & [met] & {$\left[\mathrm{W} \cdot \mathrm{m}^{-2}\right]$} \\
\hline Washing by hand and ironing & 1.3 to 2.9 & 76 to 169 & Swimming & 7.5 to 8.7 & 436 to 506 \\
\hline \multirow{2}{*}{$\begin{array}{l}\text { Making a fire in an open } \\
\text { fireplace or in a stove }\end{array}$} & 1.4 to 1.6 & 79 to 90 & Biking (long-distance) & 7.2 to 8.0 & 419 to 463 \\
\hline & & & \multicolumn{3}{|l|}{ Dancing } \\
\hline Shopping & 0.7 to 1.1 & 41 to 64 & Social & 1.7 to 3.7 & 99 to 215 \\
\hline \multicolumn{3}{|l|}{ OFFICE WORK } & Waltz & 3.9 & 226 \\
\hline Typing & 0.5 to 0.7 & 29 to 41 & Polka & 7.2 & 419 \\
\hline Miscellaneous office work & 0.4 to 0.6 & 23 to 35 & Tennis, singles & 2.9 to 3.9 & 169 to 227 \\
\hline Drafting & 0.4 to 0.6 & 23 to 35 & Squash, singles & 4.3 to 6.3 & 250 to 378 \\
\hline \multicolumn{3}{|l|}{ LEISURE ACTIVITIES } & Basketball, half court, indoors & 4.3 to 6.9 & 250 to 402 \\
\hline Stream fishing & 0.5 to 1.3 & 29 to 76 & \multirow{2}{*}{$\begin{array}{l}\text { Wrestling-competitive or } \\
\text { intensive }\end{array}$} & \multirow[t]{2}{*}{6.3 to 8.0} & \multirow[t]{2}{*}{367 to 466} \\
\hline Calisthenics exercise & 2.3 to 3.3 & 134 to 192 & & & \\
\hline Jogging (long-distance) & 6.6 & 381 & Golf, swinging and walking & 0.7 to 1.9 & 41 to 111 \\
\hline Table-tennis, singles & 3.4 & 196 & Golf, swinging and golf cart & 0.7 to 1.1 & 41 to 64 \\
\hline
\end{tabular}

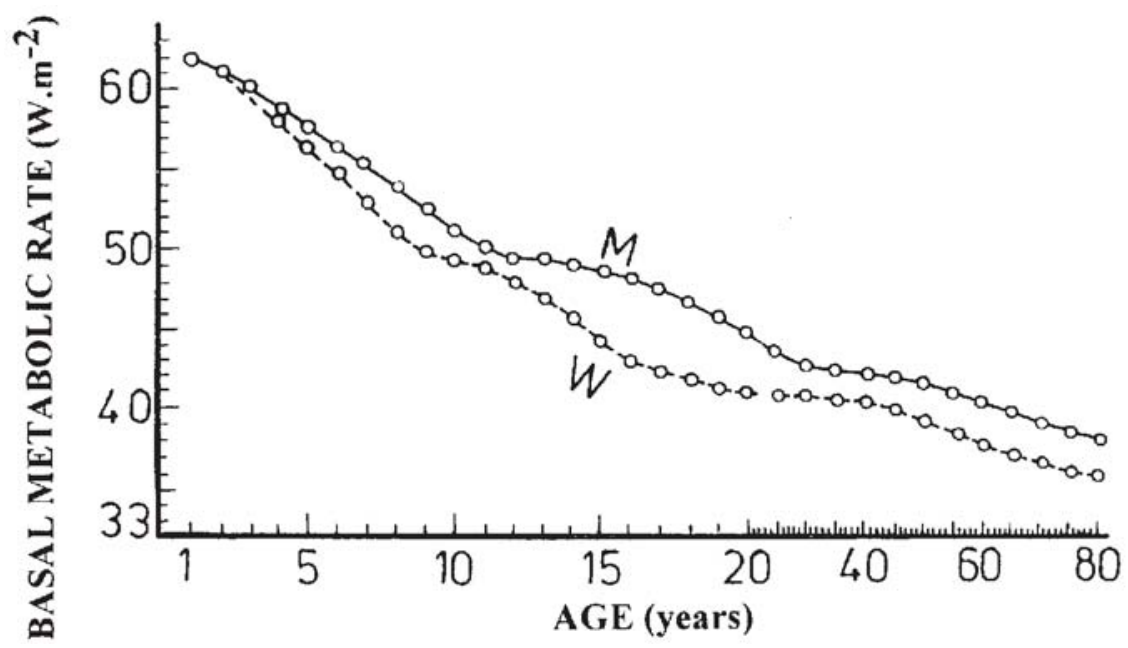

Fig. 2: Basal heat production by human beings (basal metabolic rate $q_{\mathrm{m}, \mathrm{b}}$ ). For the standard man of average weight and height $(75 \mathrm{~kg}$, $175 \mathrm{~cm})$ surface $=1.9 \mathrm{~m}^{2}$

\subsection{Sources of water vapor}

The water vapor content in an interior is determined by both the water vapor content in outdoor air and the water vapor sources inside a building. In winter, as a result of low air temperatures, the water vapor content in outdoor air is low (the vapor is condensed or even frozen and falls to the earth). Thus the air coming indoors is very dry after warming to the indoor temperature, and the relative humidity may even drop below $20 \%$. In summer, when the air temperatures are high, the water vapor content in outdoor air is high, due to higher air saturation by water vapor [6], [11], [12]. Thus the air coming indoors is almost saturated with water vapor, after cooling to the indoor temperature, and the relative air humidity can even reach $100 \%$.

Water vapor indoors also results mostly from various human activities, especially having a shower (about $2600 \mathrm{~g} / \mathrm{h}$ ), cooking (up to $1500 \mathrm{~g} / \mathrm{h}$ ), drying linen (up to $500 \mathrm{~g} / \mathrm{h}$ ), pot plants (up to $20 \mathrm{~g} / \mathrm{h}$ ) and also human beings themselves (30 up to $300 \mathrm{~g} / \mathrm{h}$ ) (see Table 2 ).

Table 2: Sources of water vapor in an apartment

\begin{tabular}{|c|c|}
\hline HUMANS light activity & $30-60 \mathrm{~g} / \mathrm{h}$ \\
\hline medium heavy work & $120-300 \mathrm{~g} / \mathrm{h}$ \\
\hline heavy work & $200-300 \mathrm{~g} / \mathrm{h}$ \\
\hline BATHROOM with bath & about $700 \mathrm{~g} / \mathrm{h}$ \\
\hline with shower & about $2600 \mathrm{~g} / \mathrm{h}$ \\
\hline KITCHEN during cooking & $600-1500 \mathrm{~g} / \mathrm{h}$ \\
\hline daily average & $100 \mathrm{~g} / \mathrm{h}$ \\
\hline
\end{tabular}




\begin{tabular}{|l|c|}
\hline \multicolumn{2}{|c|}{ DRYING LINEN (washer for $4.5 \mathrm{~kg}$ ) } \\
\hline \multicolumn{1}{|c|}{ drip } & $0-200 \mathrm{~g} / \mathrm{h}$ \\
\hline POOLS (free water surface) & $100-500 \mathrm{~g} / \mathrm{h}$ \\
\hline PLANTS & about $40 \mathrm{~g} / \mathrm{m}^{2} \mathrm{~h}$ \\
\hline Indoor flowers, e.g. violet (Viola) & $5-10 \mathrm{~g} / \mathrm{h}$ \\
\hline $\begin{array}{l}\text { Flowers in pot, } \\
\text { e.g. fern (Comptonia asplemifolia) }\end{array}$ & $7-15 \mathrm{~g} / \mathrm{h}$ \\
\hline $\begin{array}{l}\text { Fig plant of medium size } \\
\text { (Ficus elastica) }\end{array}$ & $10-20 \mathrm{~g} / \mathrm{h}$ \\
\hline $\begin{array}{l}\text { Water plants, } \\
\text { e.g. water-lily (Nymphea alba) }\end{array}$ & $6-8 \mathrm{~g} / \mathrm{h}$ \\
\hline $\begin{array}{l}\text { Young trees (2/3 m tall), } \\
\text { e.g. beech (Fagus) }\end{array}$ & $2-4 \mathrm{~kg} / \mathrm{h}$ \\
\hline $\begin{array}{l}\text { Grown trees (25 m), } \\
\text { e.g. spruce (Picea) }\end{array}$ & $2-3 \mathrm{~m} / \mathrm{h}$ \\
\hline
\end{tabular}

\section{Impact of heat, cold and water vapor on human beings}

Water vapor manifests itself in various ways. Particular attention must be paid to the impact of heat and cold, and to water vapor.

\subsection{Impact of heat and cold on human beings}

Humans are so called "homoiotherm organisms", i.e. they need a constant temperature at their core (for their inner bodily organs). For this purpose, they are provided with a thermoregulatory center situated in the hypothalamus (see Fig. 3), located at the center of an imaginary line connecting the auditory canals. The central location of the thermoregulatory center, with all-round protection from the head, indicates its importance. The heat center and the same time terminal center is in the anterior (front) hypothalamus (which controls vasodilatation and perspiration), while the center of cold and at the same time the "heat maintenance center" is in the posterior (rear) hypothalamus. However, the response to

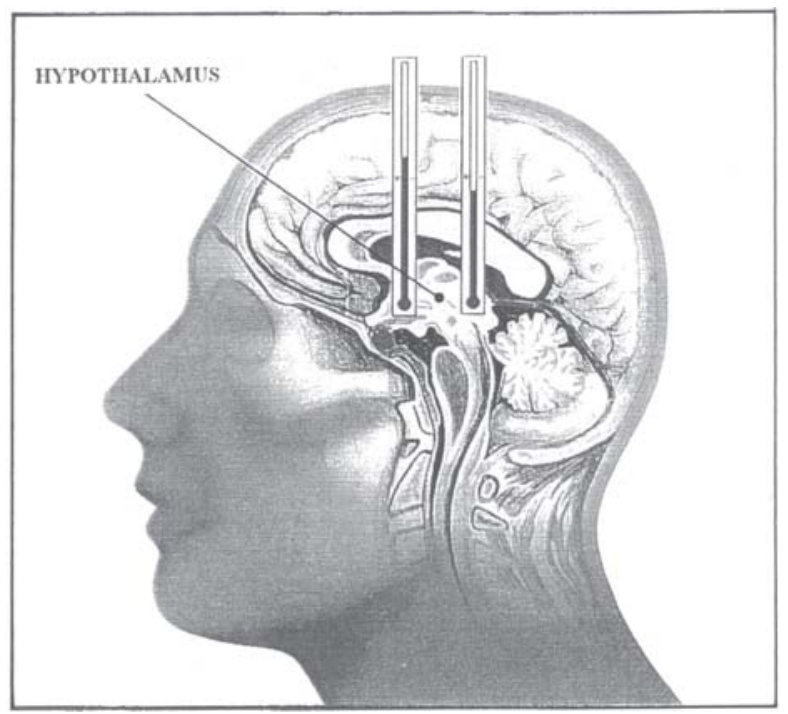

Fig. 3: Thermoregulatory centers both warmth cold is controlled by the terminal anterior center, also called the "temperature eye" or the "human thermostat", because it is able to maintain the body temperature at a strictly determined "set" temperature [6], [5].

Thermal equilibrium between the human organism and the environment is the basic condition for maintaining body temperature [6], [16], i.e., the heat produced by a human must be transferred to his environs. If more heat is transferred than is produced, as a result of an excessively cold environment, the thermal balance is disturbed downwards followed by a feeling of coldness. If less heat is transferred than is produced (as a result of an excessively warm environment), the thermal balance is disturbed upwards, followed by a feeling of warmth. In a warm or hot environment the heat balance can be restored by sweating (the body is cooled by sweat evaporation), but in a very cold environment there is no equivalent mechanism (except shivering, which rarely occurs) so excessive cooling leads to hypothermia and a decrease in body temperature. (TAUMO is practiced in Tibet: Young men compete in a contest to dry out wet bed sheets at a temperature of $-32{ }^{\circ} \mathrm{C}$. They did this with such ease that even a member of a British expedition joined on and survived!) For this reason, most hygiene regulations permit up to 4 liters of sweat production in a hot workplace, but take no account of shivering in cold workplaces.

Overheating of the human organism followed by an increase in body temperature can also occur quantity of if the quantity of evaporated sweat is not sufficient, or if the sweat cannot be evaporated (in a humid environment, in waterproof clothing). The human body temperature can be increased without risk only slightly above $38{ }^{\circ} \mathrm{C}$. Higher temperatures are dangerous.

The extent to which the human body temperature can be decreased is still under discussion; until recently $28{ }^{\circ} \mathrm{C}$ had been considered to be the critical value. However, in 1999 Norwegian doctors in Tromso were able to revive a 29-year-old woman, Ann Baagenholm from Sweden, who had fallen into a river near Narvik while on a crosscountry skiing run. She spent more than an hour in the river ice before being rescued and transported to Tromso hospital - her body temperature measured there was only $13.8^{\circ} \mathrm{C}$.

The difference between undercooling and catching cold depends only on one's state of health, i.e., on one's immunobiological resistance. In every day practice, it is important that people are protected against excessive heat by sweating, but there is no protection against excessive cold - there is a danger of undercooling and also of catching cold.

Thus when a person feels cold, immediate action is necessary: increased thermal/insulating properties of clothing, a higher air temperature, intensive physical activity, etc.

However, the heat balance of the human organism is not a sufficient condition for hydrothermal comfort. Radiant comfort must be added, i.e., heat balance of the body must be provided by external radiant heat (we are used to solar radiation), and heat must be released by convection to the outside (cooling by wind in nature). This physiological fact is expressed as the so called Radiant Comfort Coefficient RCC. This expresses the ratio of radiant and convective heat:

$$
\mathrm{RCC}=\frac{\text { body radiation }}{\text { body convection }} \geq 1 \text {. }
$$


RCC should be higher than or equal to one for optimum conditions. This limit enables another hygienic requirement for interiors to be estimated: the acceptable difference between air temperature and surface, wall temperature, and the corresponding difference between air temperature and globe temperature in winter. It is clear that, in a cellar with low wall temperatures, where the optimum limit for RCC cannot be achieved, we feel less comfortable than in front of an open fireplace with the optimum limit provided. The sum of the convective and radiative heat is, of course, the same in both cases.

Besides thermal equilibrium and radiant comfort, the human organism is also sensitive to uniform heat transfer to the surroundings both in space and in time. In space, the cooling of the ankles must not be too different from the cooling of the head, i.e., the temperatures at ankle and head level must not be too different, and air streaming must also be taken into account (drafts should be avoided). In time, the temperature oscillations during a day in the same place or when passing from one room to another without a change of clothes [7], [8], [9], [11], [12], [13] must not exceed the thermoregulatory range of the human body.

Some locations on the human body surface are extremely sensitive to undercooling, and therefore need to be carefully protected (see Fig. 4). They are: the neck (the thyroid gland is a part of the thermoregulatory system), below the shoulder blade (purine agents sedimentate in this area), the kidneys (kidney belts made of special fur seem to be useful), the small of the back (the area where people most often feel pain, and local cold stress may result in painful lumbago), and the ankles, which are directly connected to the upper breathing passages (when the ankles are immersed into cold water the temperature of these passages, e.g. the inside of the nose, immediately drops, and microbes multiply, leading to sneezing). Everybody knows that wet shoes will soon lead to sneezing.

Temperature changes when passing from one environment to another one are a chronic problem in hot countries, i.e., in the subtropics and tropics. In the Persian Gulf where $50{ }^{\circ} \mathrm{C}$ and $100 \%$ relative humidity can occur in summer, the air temperature is maintained at about $20^{\circ} \mathrm{C}$ inside hotels and many other buildings. Foreign visitors are liable to catch colds, and residents are liable to rheumatism followed by arthritis.

\subsection{Impact of water vapor on human beings}

There are problems with low relative air humidity in winter, when air coming from outdoors contains just a small quantity of water, and with high relative air humidity in summer, especially during rainy weather.

A sensation of dryness is caused by drying out of the mucosa in the upper breathing passages, leading to a disturbance of the protective nasal function, which acts as a sort of filter for aerosols (especially dust, including allergens) (see Fig. 5). The cilia in the mucosa are continuously in motion, and prevent dust sedimentation, as can be seen under a microscope. According to Evert [14] mucus (slimy substance) production depends mainly on the relative humidity of the inspired air: mucus production and cilia movement decreases rapidly below a relative humidity of $40 \%$. This produces optimum conditions for microbe multiplication. Low air humidity

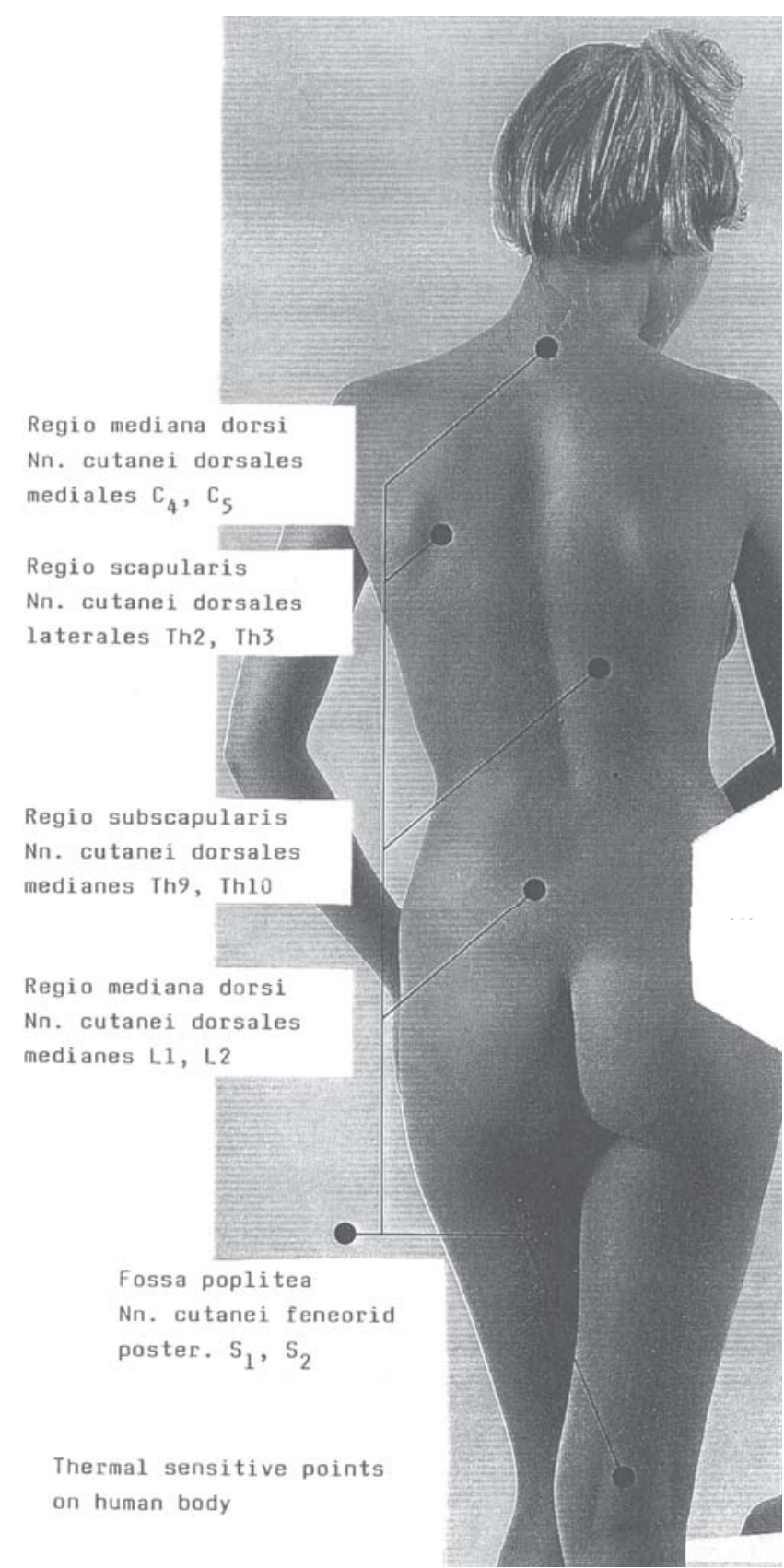

Fig. 4: Locations on the human body sensitive to cold

also has a negative impact on skin and eyes and on static electricity production.

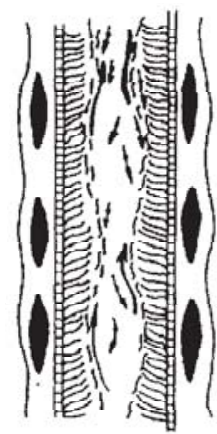

A
B

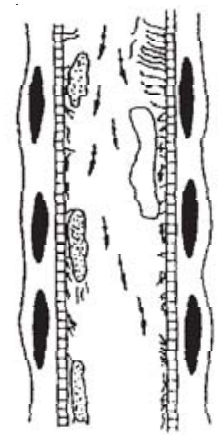

Fig. 5: Mucosa of the upper respiratory pathways in normal condition (A), and dried out (B) 
Relative humidity not only affects feelings of comfort but also has a direct impact on human health. Green investigated the occurrence of influenza and runny noses in children at school [6]. There was a significant difference between classrooms with humidified and nonhumidified air. The results taken by Ritzel from five kindergartens are even more significant: in the investigated classrooms with air humidification the occurrence of upper respiratory infections was not much more than half the occurrence in classrooms (control group) without humidification (Table 3). The explanation may be shown in Fig. 6: adenoviruses, which produce colds, have their lowest survival rate at about $60 \%$ relative air humidity. Particles causing severe allergies, e.g., pollen, domestic dust often containing hairs and particles from the skin of pets, particles of mites etc., spread most freely in conditions of low air humidity.

Table 3: Effects of relative air humidity on upper respiratory infections in kindergartens

\begin{tabular}{|l|c|c|c|}
\hline Microclimate & $\begin{array}{c}\text { Total student } \\
\text { study days }\end{array}$ & $\begin{array}{c}\text { Absent days } \\
\text { (colds) }\end{array}$ & $\begin{array}{c}\text { Absenteeism } \\
{[\%]}\end{array}$ \\
\hline $\begin{array}{l}\text { Humidified } \\
(\mathrm{rh}=49 \%, \\
\left.\mathrm{T}_{\mathrm{a}}=22^{\circ} \mathrm{C}\right)\end{array}$ & 9306 & 195 & 3.0 \\
\hline $\begin{array}{l}\text { Unhumidified } \\
(\mathrm{rh}=40 \%, \\
\left.\mathrm{T}_{\mathrm{a}}=22^{\circ} \mathrm{C}\right)\end{array}$ & 5910 & 138 & 5.7 \\
\hline
\end{tabular}

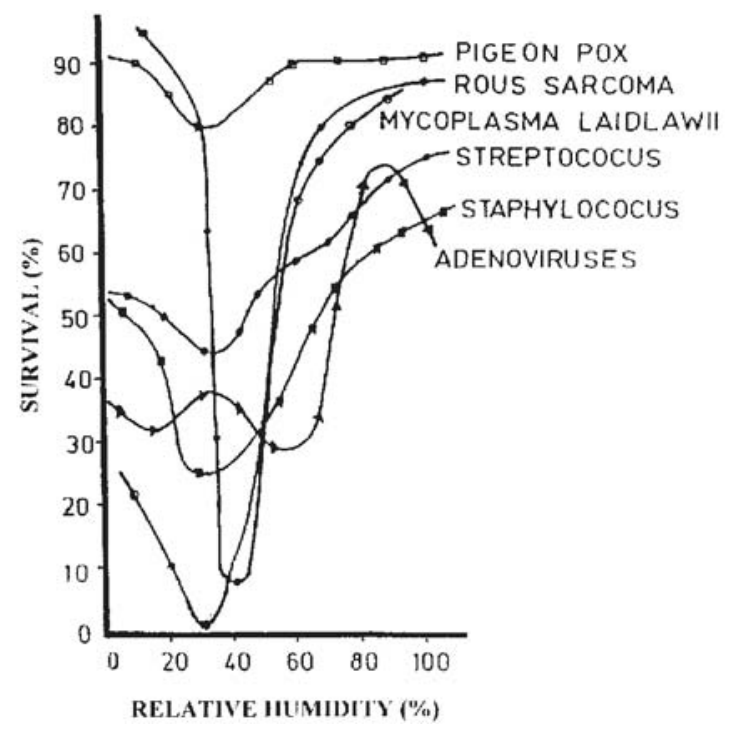

Fig. 6: The percentage of microorganism survivals in the air with increased relative air humidity

High relative humidity - over $70 \%$ (over $50 \%$ for people with high sensitivity) in combination with high air - temperature produces a feeling of sultriness, and can even lead to health problems. It enables the spread of airborne molds and multiplication of mites (see Fig. 7), thus producing breathing problems, sore throats, headaches, runny noses and nervous problems in adults, and especially in children. The number and intensity of these problems increases proportionally to the humidity in the accommodation the children live in (according to Dr Platt, from the Epidemiological Unit of Medical Research at the Royal Edinburgh Hospital, U.K.)

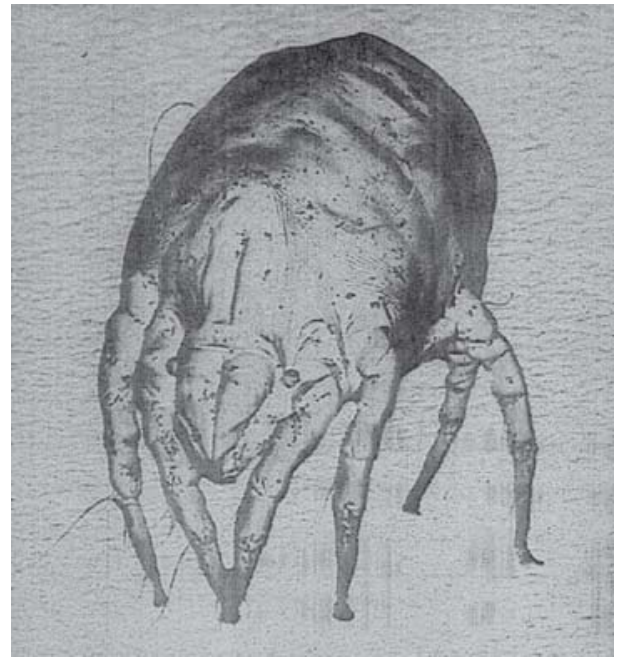

Fig. 7: A mite, living in a building interior (magnified, real size about $0.1 \mathrm{~mm}$ )

Mites are the main source of allergies in Denmark, according to research by Gullev [3]. They cause allergies in 200000 Danes. Cats and dog hair, mold spores, and cigarette smoke cause a smaller number of allergies.

The use of a vacuum cleaner is very effective against mites in carpets and other textiles, which feed on the remains of human skin (immediately after use, the filter must be emptied out). Decreasing the relative air humidity below $45 \%$ for period of several days is also effective.

Special natural sprays have been developed against mites. ALLERSEARCH, developed in Australia, contains plant substances that repel mites for at least six months. These natural substances are not harmful for humans, since they act by changing the structure of the proteins in the bodies of mites. Insecticides, which used to be used, are harmful to the human body human body, and are no longer very effective against mites. ARTILIN is applied with a brush, and kills mites on contact, and also destroys the molds that feed mites and give them shelter. Painting is effective for at least five years.

\section{Hydrothermal microclimate standards}

Two hydrothermal microclimate standards are particularly influential in the world today: The US ANSI/ASHRAE National Standard 55-1992, with Addendum ANSI/ASHRAE 55a-1995 Thermal Environmental Conditions for Human Occupancy, and the European International Standard ISO 7730 Moderate thermal environments.

\subsection{ANSI/ASHRAE Standard 55-1992 Thermal environmental conditions for human occupancy}

The purpose of this standard is to specify the combinations of indoor space environment and personal factors that 
Table 4: Clothing insulation values for typical ensembles

Ensemble

1. briefs; knit, short-sleeve sport shirts; walking shorts; belt; calf-length socks; hard-soled shoes

2. panties; broadcloth, short-sleeve shirt; A-line, knee-length skirt; pantyhose; thongs/sandals

3. briefs; broadcloth, long-sleeve shirt; long fitted trousers; calf-length socks; hard-soled shoes

4. panties; full slip; broadcloth, short-sleeve shirt; belted A-line dress; long-sleeve cardigan sweater; pantyhose; hard-soled shoes

5. panties; broadcloth, long-sleeve shirt; sleeveless round-neck sweater; thick walking shorts; belt; thick knee socks; hard-soled shoes

6. panties; half-slip; broadcloth, long-sleeve blouse; single-breasted suit jacket; A-line, knee-length skirt; pantyhose; thongs/sandals

7. briefs; thermal long underwear top; thermal long underwear bottoms; flannel, long-sleeve shirt; overalls; calf-length sock; hard-soled shoes

8. briefs; broadcloth, long-sleeve shirt; single-breasted suit jacket; tie; straight, long fitted trousers; calf-length socks; hard-soled shoes

9. briefs; t-shirt; broadcloth, long-sleeve shirt; long-sleeved, round-neck sweater; thick, straight, long, loose trousers; belt; calf-length sock, hard-soled shoes

10. panties; broadcloth, long-sleeve shirt; thick vest; thick, single-breasted suit jacket; thick, A-line, knee-length skirt; pantyhose; hard-soled shoes

11. briefs; t-shirt; broadcloth, long-sleeve shirt; thick vest; thick, single-breasted suit jacket; thick, straight, long, loose trousers; belt; calf-length socks; hard-soled shoes

12. briefs; t-shirt; flannel, long-sleeve shirt; work jacket; belt; work pants; calf-length socks; hard-soled shoes

13. flannel, long-sleeve, long nightgown; thick, long-sleeve, wrap, long robe; slippers

will produce hydrothermal environmental conditions acceptable to $80 \%$ or more of the occupants within the space.

The environmental factors addressed are temperature, thermal radiation, humidity and air speed; the personal factors are those of activity and clothing.

This standard specifies the hydrothermal environmental conditions acceptable for healthy people at atmospheric pressure equivalent to altitudes up to $3000 \mathrm{~m}$ in indoor spaces designed for human occupancy for periods of not less than 15 minutes.

Clothing, through its insulative properties, is an important modifier of body heat loss and comfort. Clothing or garment insulation is quantified in clo units. In this standard, the intrinsic insulation value $\left(\mathrm{I}_{\mathrm{cl}}\right)$ is used to describe the insulation provided by clothing ensembles. Clothing insulation values for selected ensembles are given in Table 4. A heavy business suit with its accompanning garments usually has a clo value of 1 .

Clo: a unit used to express the thermal insulation provided by garments and clothing ensembles, where $1 \mathrm{clo}=0.155 \mathrm{~m}^{2} \cdot{ }^{\circ} \mathrm{C} / \mathrm{W}\left(0.88 \mathrm{ft}^{2} \cdot \mathrm{h} \cdot{ }^{\circ} \mathrm{F} / \mathrm{Btu}\right)$.
Insulation, clothing $\left(\mathrm{I}_{\mathrm{cl}}\right)$ : the resistance to sensible heat transfer provided by a clothing ensemble (i.e., more than one garment). It is described as the intrinsic insulation from the skin to the clothing surface, not including the resistance provided by the air layer around the clothed body; it is usually expressed in clo units.

Temperature, operative $\left(t_{0}\right)$ : the uniform temperature of an imaginary black enclosure in which an occupant would exchange the same amount of heat by radiation plus convection as in the actual nonuniform environment. Operative temperature is numerically the average of the air temperature $\left(\mathrm{t}_{\mathrm{a}}\right)$ and mean radiant temperature $\left(\bar{t}_{\mathrm{r}}\right)$, weighted by their respective heat transfer coefficients $\left(h_{c}\right.$ and $\left.h_{\mathrm{r}}\right)$ :

$$
t_{0}=\left(h_{\mathrm{c}} t_{\mathrm{a}}+h_{\mathrm{r}} \bar{t}_{\mathrm{r}}\right) /\left(h_{\mathrm{c}}+h_{\mathrm{r}}\right) .
$$

The operative temperature is approximately equal to the globe temperature (Fig. 8).

The operative temperatures and clothing insulation values corresponding to the sensation of neutral and the $10 \%$ dissatisfaction criterion are given in Fig. 9. 
Table 5: Optimum and acceptable ranges of operative temperature for people during light, primarily sedentary activity (1.2 met) at $50 \%$ relative humidity and mean air speed $0.15 \mathrm{~m} / \mathrm{s}(30 \mathrm{fpm})^{*}$

\begin{tabular}{|c|c|c|c|c|}
\hline Season & Description of typical clothing & $\begin{array}{c}\mathrm{I}_{\mathrm{cl}} \\
{[\mathrm{clo}]}\end{array}$ & $\begin{array}{l}\text { Optimum operative } \\
\text { temperature }\end{array}$ & $\begin{array}{c}\text { Operative temperative } \\
\text { range } \\
(10 \% \text { dissatisfaction } \\
\text { criterion })\end{array}$ \\
\hline \multirow[t]{2}{*}{ Winter } & \multirow[t]{2}{*}{ heavy slacks, long-sleeve shirt and sweater } & \multirow[t]{2}{*}{0.9} & $22^{\circ} \mathrm{C}$ & $20-23.5^{\circ} \mathrm{C}$ \\
\hline & & & $71^{\circ} \mathrm{F}$ & $68-75^{\circ} \mathrm{F}$ \\
\hline \multirow[t]{4}{*}{ Summer } & \multirow[t]{2}{*}{ light slacks and short-sleeve shirt } & \multirow[t]{2}{*}{0.5} & $24.5^{\circ} \mathrm{C}$ & $23-26^{\circ} \mathrm{C}$ \\
\hline & & & $76^{\circ} \mathrm{F}$ & $73-79^{\circ} \mathrm{F}$ \\
\hline & \multirow[t]{2}{*}{ minimal } & \multirow[t]{2}{*}{0.05} & $27^{\circ} \mathrm{C}$ & $26-29^{\circ} \mathrm{C}$ \\
\hline & & & $81^{\circ} \mathrm{F}$ & $79-84^{\circ} \mathrm{F}$ \\
\hline
\end{tabular}

*Other than clothing, there are no adjustments for season or sex to the temperatures in Table 5. For infants, certain elderly people, and individuals who are physically disabled, the ower limits of Table 5 should be avoided.

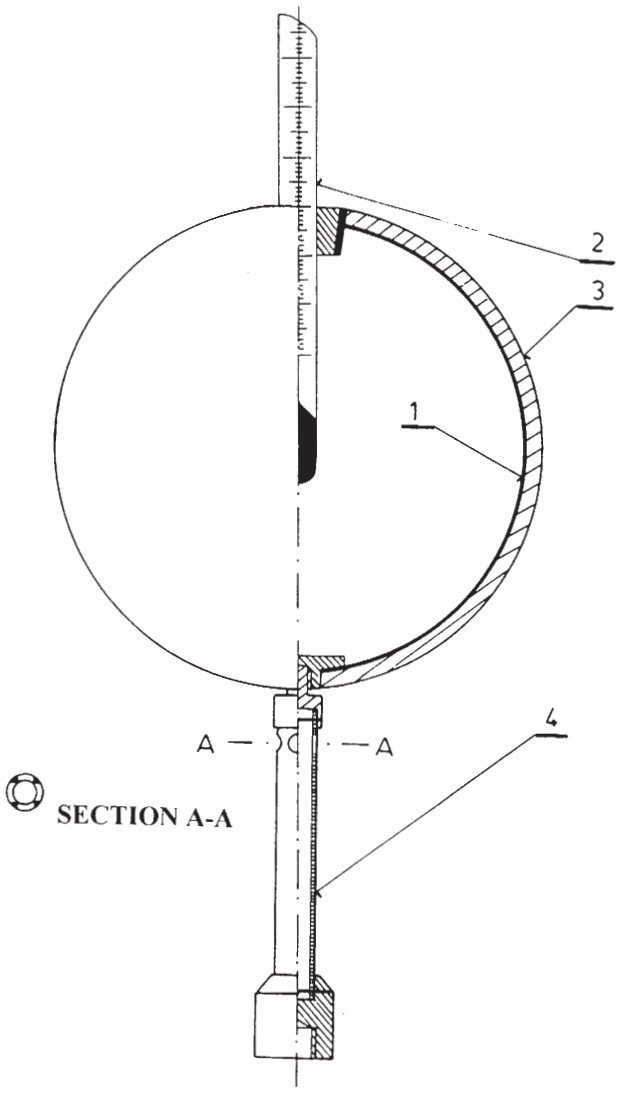

Fig. 8: The Vernon-Jokl globe thermometer (1 thin copper globe, 2 thermometer, 3 polyurethane, 4 fastening stand)

The acceptable range of operative temperatures and humidities for winter and summer is given in Table 5 , and is further defined in the psychometric chart in Fig. 10.

Comfort conditions for clothing levels different from those given above can be determined approximately by lowering the temperature ranges of Table 5 or Fig. 10 by $0.6{ }^{\circ} \mathrm{C}$ $\left(1^{\circ} \mathrm{F}\right)$ for each 0.1 clo of increased clothing insulation. However, at lower temperatures, comfort depends on the maintenance of a reasonably uniform distribution of clothing insulation over the entire body and, in particular, for hands

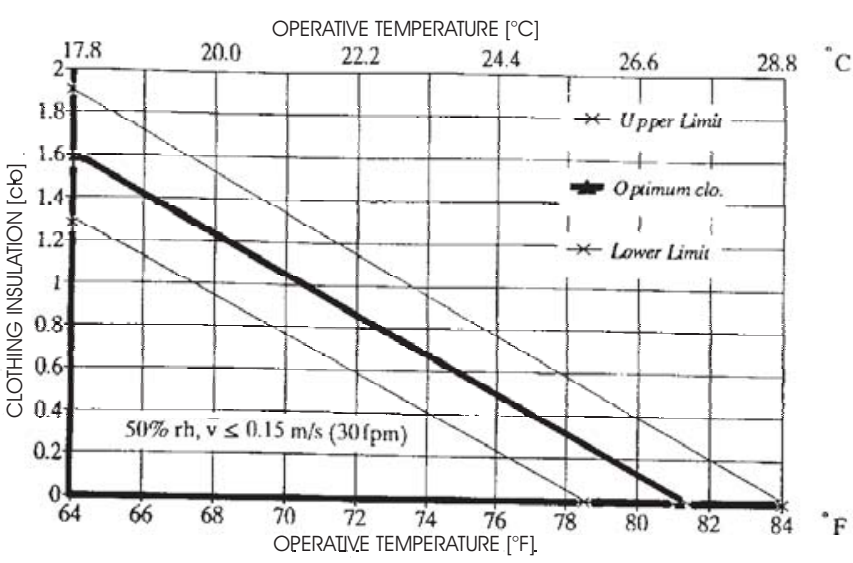

Fig. 9: The recommended range of clothing insulation providing acceptable thermal conditions at a given operative temperature for people during light, primarily sedentary activity $(\leq 1.2 \mathrm{met})$ according to ANSI/ASHRAE Standard 55-1992. The limits are based on a $10 \%$ dissatisfaction criterion.

and feet. For sedentary occupancy of more than an hour, the minimum operative temperature should not be less than $18{ }^{\circ} \mathrm{C}\left(65^{\circ} \mathrm{F}\right)$. Within the thermally acceptable temperature ranges of Table 5 and Fig. 10 there is no minimum air speed that is necessary for thermal comfort. For sedentary persons, it is essential to avoid drafts. Requirements on avoiding drafts are given in the section dealing with nonuniformity of the heat load on humans (see later).

The temperature may be increased above the level allowed for the comfort zone if a means is provided for also elevating the air speed. The benefits that can be gained by increasing the air speed depend on clothing, activity, and the difference between the surface temperature of the clothing/skin and the air temperature. Fig. 11 shows the air speed that is required for clothing and for activities that correspond to the summer comfort zone in Fig. 10. For sedentary people, this option may not be used to increase the temperature by more than $3{ }^{\circ} \mathrm{C}\left(5.4^{\circ} \mathrm{F}\right)$ above the comfort zone and it may not be used if the speed required is more than $0.8 \mathrm{~m} / \mathrm{s}(160 \mathrm{fpm})$. The air speed and/or direction in work locations must be 

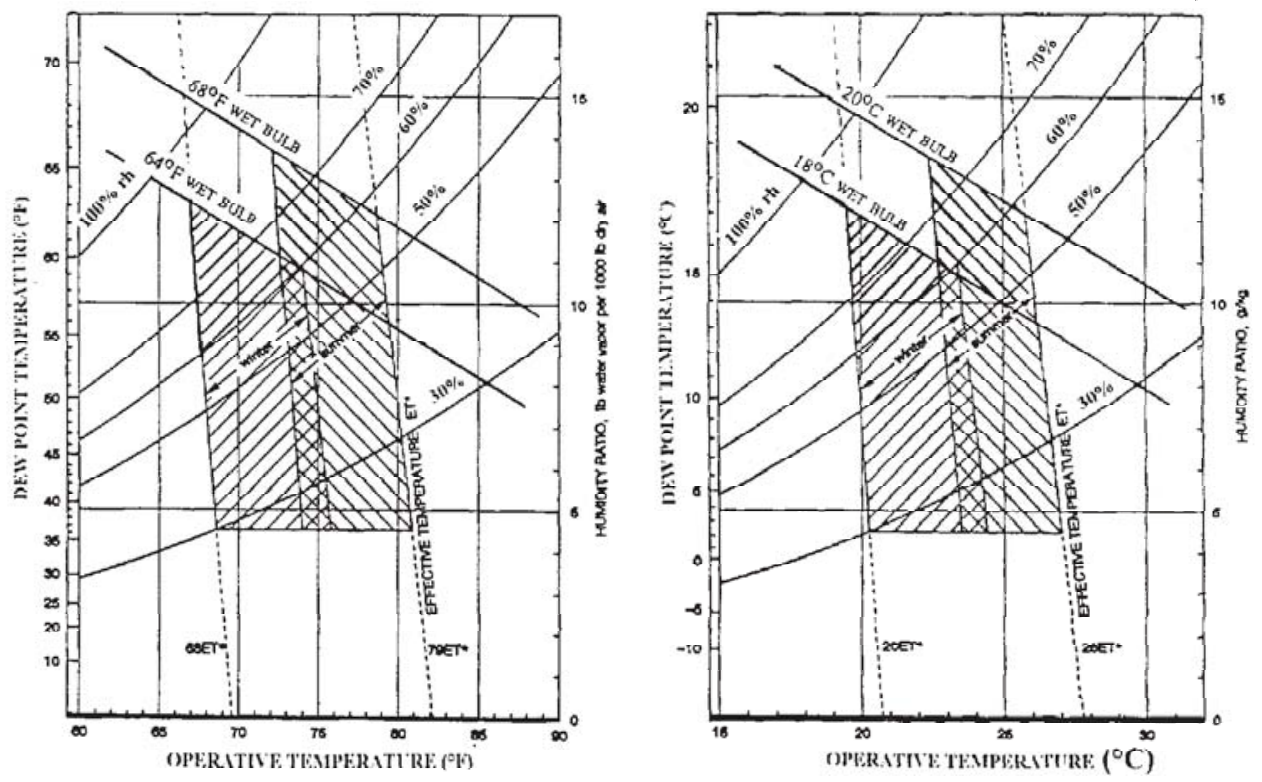

Fig. 10: Acceptable ranges of operative temperature and humidity for people in typical summer and winter clothing during light, primarily sedentary activity ( $\leq 1.2 \mathrm{met})$ according to ANSI/ASHRAE Standard 55-1992. The operative temperature ranges are based on a $10 \%$ dissatisfaction criterion.

under the direct control of the affected occupants and adjustable in steps no greater than $0.25 \mathrm{~m} / \mathrm{s}(50 \mathrm{fpm})$ if this option is used.

TEMPERATURE RISE $\left({ }^{\circ} \mathrm{C}\right)$

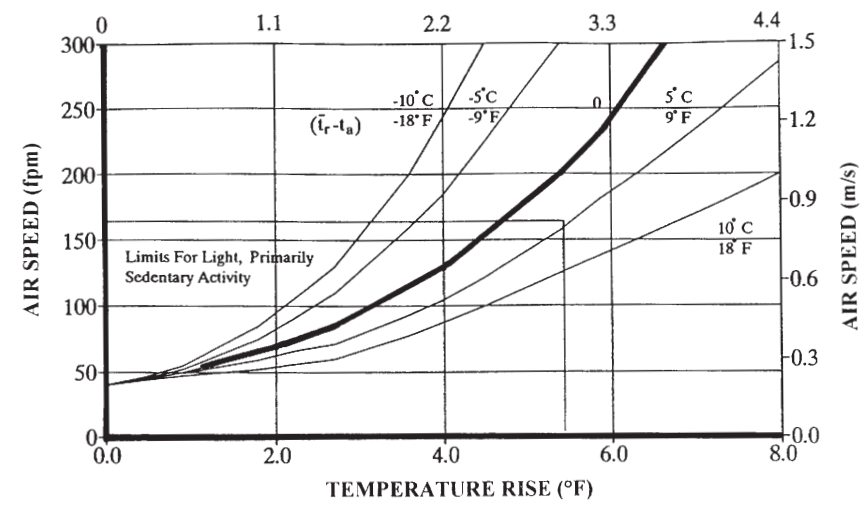

Fig. 11: Air speed required to offset increased temperature according to ANSI/ASHRAE Standard 55-1992. The air speed increases in the amount necessary to maintain the same total heat transfer from the skin. This figure applies to increases in temperature above those allowed in the summer comfort zone with both $\bar{t}_{\mathrm{r}}$ and $t_{\mathrm{a}}$ increasing equally. The starting point of the curves at $0.2 \mathrm{~m} / \mathrm{s}(\mathrm{fpm})$ corresponds to the recommended air speed limit for the summer comfort zone at $26^{\circ} \mathrm{C}\left(79^{\circ} \mathrm{F}\right)$ and typical ventilation (i.e., turbulence intensity between $30 \%$ and $60 \%$ ). Acceptance of the increased air speed requires occupant control of the local air speed.

\subsubsection{Nonsteady state}

Problems of nonsteady state concern mainly temperature cycling and temperature drifts or ramps.

Temperature Cycling. If the peak cyclic variation (time period less than 15 minutes) in the operative temperature exceeds $1.1^{\circ} \mathrm{C}\left(2^{\circ} \mathrm{F}\right)$ the rate of temperature change shall not exceed $2.2^{\circ} \mathrm{C} / \mathrm{h}\left(4^{\circ} \mathrm{F} / \mathrm{h}\right)$. There are no restric- tions on the rate of temperature change if the peak - to peak difference is $1.1^{\circ} \mathrm{C}\left(2^{\circ} \mathrm{F}\right)$ or less.

Temperature Drifts or Ramps. Temperature drifts and ramps are monotonic, steady, noncyclic operative temperature changes. Drifts refer to passive temperature changes of the enclosed space, and ramps refer to actively controlled temperature changes. The maximum allowable drift or ramp condition from a steady-state starting temperature of between $21^{\circ} \mathrm{C}$ and $23.3^{\circ} \mathrm{C}\left(70^{\circ} \mathrm{F}\right.$ and $\left.74^{\circ} \mathrm{F}\right)$ is a rate of $0.5^{\circ} \mathrm{C} / \mathrm{h}\left(1^{\circ} \mathrm{F} / \mathrm{h}\right)$. This drift or ramp change should not extend beyond the upper operative temperature limits of the comfort zone guidelines (specified in Fig. 10) by more than $0.5^{\circ} \mathrm{C}\left(1^{\circ} \mathrm{F}\right)$ and should not remain beyond this temperature zone for longer than one hour.

\subsubsection{Nonuniformity}

Nonuniformity of the hydrothermal environment (vertical temperature difference, radiant temperature asymmetry, warm or cold floors, and draft, see Fig. 12 for a total view) may cause local discomfort.

Vertical Air Temperature Difference. Air temperature in an enclosed space generally increases from floor to ceiling. If this increment is sufficiently large, local warm discomfort can occur at the head and/or cold discomfort at the feet, although the body as a whole is thermally neutral.

Therefore, to prevent local discomfort, the vertical air temperature difference within the occupied zone, mea-

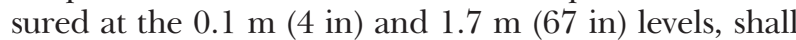
not exceed $3{ }^{\circ} \mathrm{C}\left(5^{\circ} \mathrm{F}\right)$ (Fig. 13).

Radiant Temperature Asymmetry. Asymmetric radiation from hot and cold surfaces and from direct sunlight can cause local discomfort and reduce the thermal acceptability of the space. In general, people are more sensitive to asymmetric radiation caused by a warm ceiling than that caused by hot and cold vertical surfaces. Thus, to 


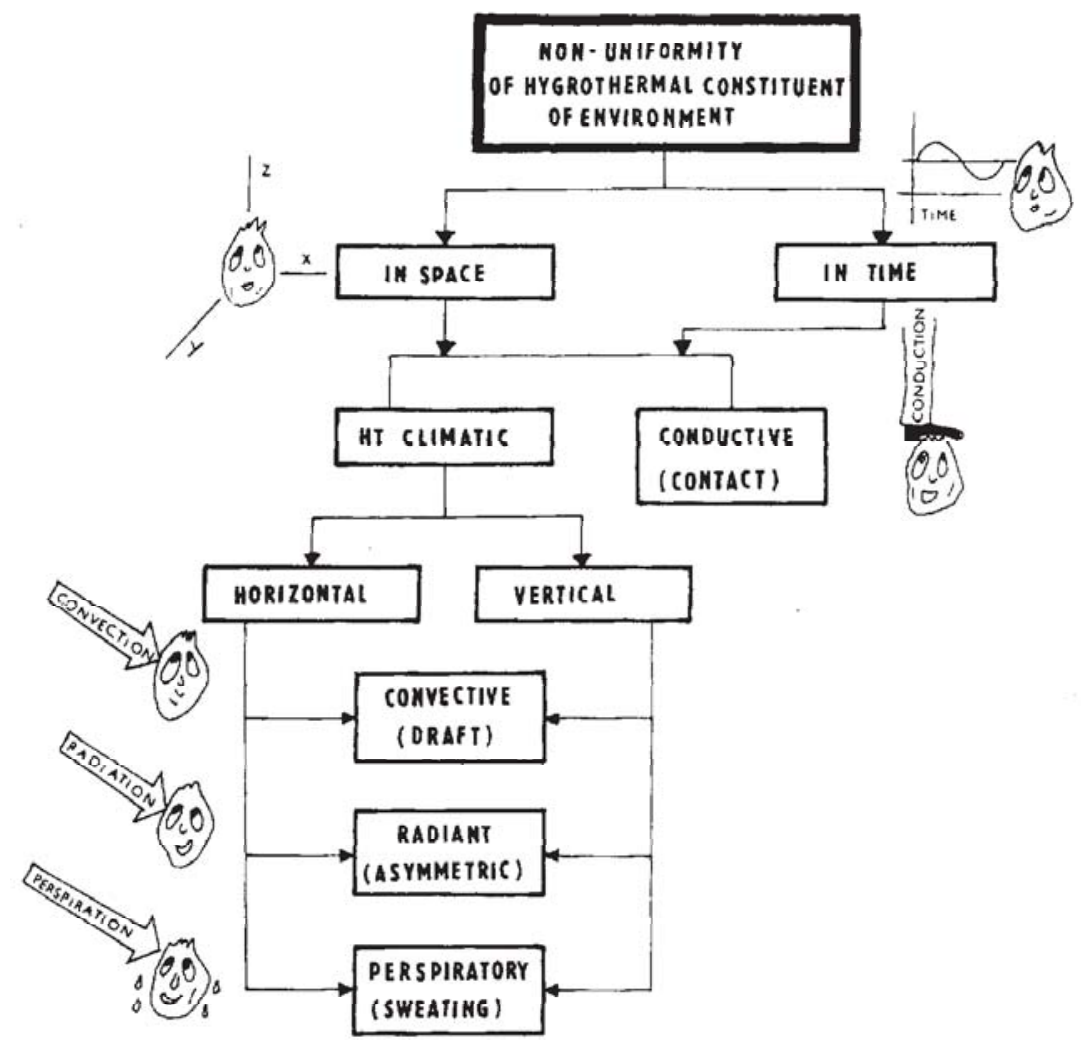

Fig. 12: Types of NUN (nonuniformity of the hydrothermal environment)

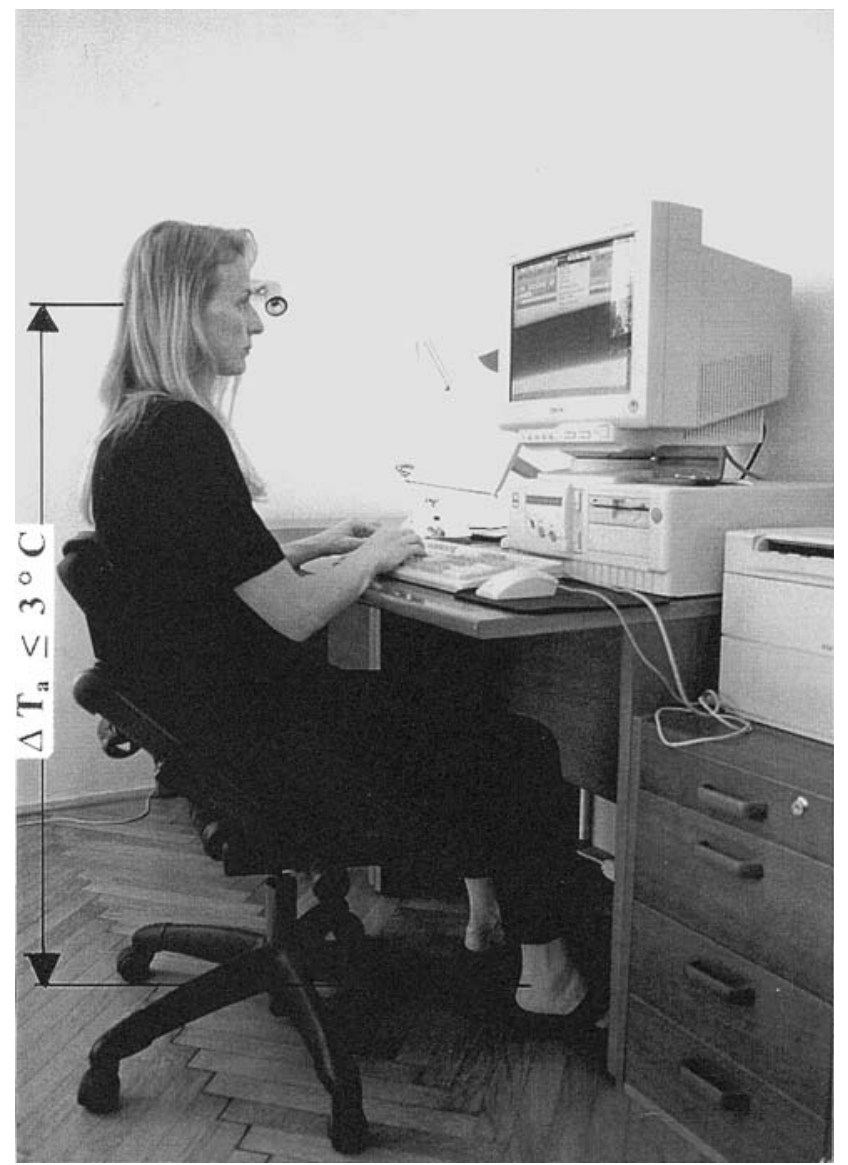

Fig. 13: Acceptable air temperature decrease at ankle level and at head level limit local discomfort, radiant temperature asymmetry in the vertical direction shall be less than $5^{\circ} \mathrm{C}\left(9^{\circ} \mathrm{F}\right)$ and in the horizontal direction less than $10^{\circ} \mathrm{C}\left(18^{\circ} \mathrm{F}\right)$. The radiant temperature asymmetry in the vertical direction is the difference in plane radiant temperature of the upper and lower parts of the space with respect to a small horizontal plane $0.6 \mathrm{~m}(2 \mathrm{ft})$ [seated] or $1.1 \mathrm{~m}(3.6 \mathrm{ft})$ [standing] above the floor. In the horizontal direction, it is the difference in plane radiant temperatures in opposite directions from a small vertical plane $0.6 \mathrm{~m}(2 \mathrm{ft})$ [seated] or $1.1 \mathrm{~m}(3.6 \mathrm{ft})$ [standing] above the floor.

Floor Temperatures. To minimize foot discomfort, the surface temperature of the floor for people wearing typical indoor footwear shall be between $18^{\circ} \mathrm{C}\left(65^{\circ} \mathrm{F}\right)$ and $29^{\circ} \mathrm{C}$ $\left(84^{\circ} \mathrm{F}\right)$. For floors that people may occupy with bare feet, the optimum floor temperature will depend on the type of floor material.

Draft. Air speed may cause unwanted local cooling of the body, defined as draft. The risk of draft depends on the mean speed, the turbulence intensity, and the temperature of the air. Sensitivity to draft is greatest where skin is exposed at the head and ankles. Fig. 14 shows the mean air speed limits at these locations needed to limit the draft risk. Higher air speeds may be acceptable if the person has individual control of the local air speed. 


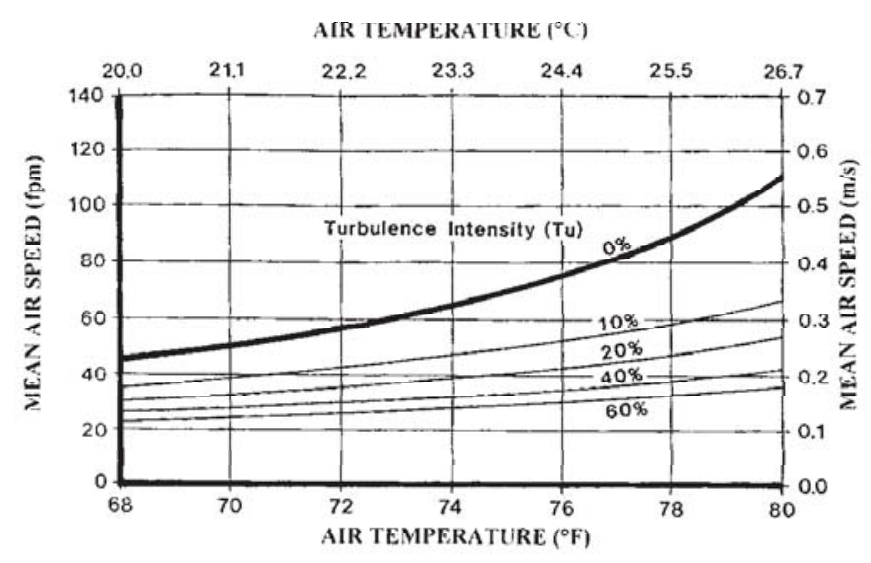

Fig. 14: Allowable mean air speed $(\bar{v})$ as a function of air temperature $\left(t_{\mathrm{a}}\right)$ and turbulence intensity $(\mathrm{Tu})$ according to ANSI/ASHRAE Standard 55-1992. The turbulence intensity may vary between $30 \%$ and $60 \%$ in conventionally ventilated spaces. In rooms with displacement ventilation or without or without ventilation, the turbulence intensity may by lower. The diagram is based on a $15 \%$ acceptable level and the sensation at the head/feet level where people are most sensitive. Higher air speeds may be acceptable if the affected occupants have control of the local air speed.

\subsubsection{People at different activity levels}

The temperatures given in Table 5 and Fig. 10 shall be decreased when the average steady-state activity level of the occupants is higher than light, primarily sedentary (> 1.2 met). The optimum operative temperature for activity depends on both the time-weighted average (e.g., about 30 to 60 minutes) activity level and the clothing insulation. This temperature can be found from Fig. 15. People with higher activity levels are not so sensitive to drafts.

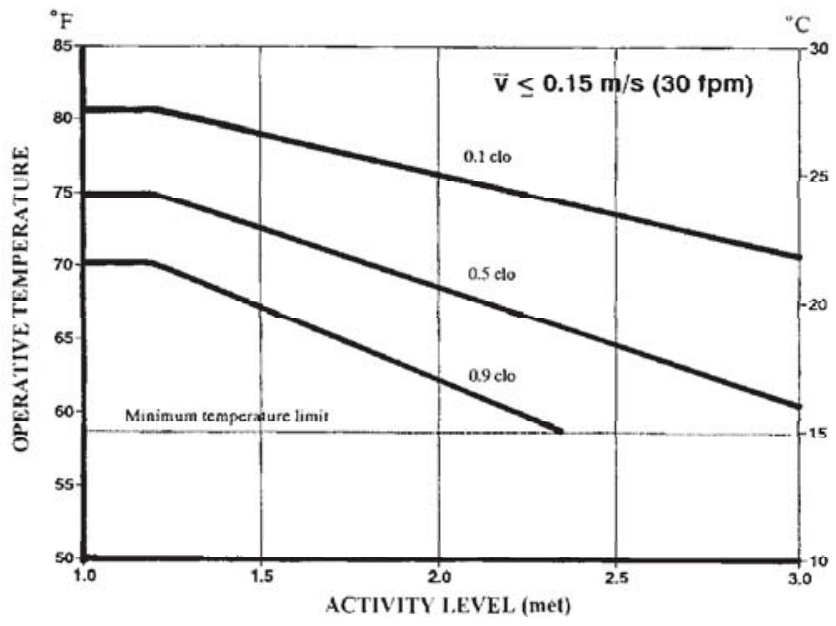

Fig. 15: Optimum operative temperatures for active people in environments with a low air speed $\bar{v} \leq 0.15 \mathrm{~m} / \mathrm{s}(30 \mathrm{fpm})$ according to ANSI/ASHRAE Standard 55-1992

\subsection{International Standard ISO 7730 moderate thermal environments}

Hydrothermal comfort is defined as that condition of mind which expresses satisfaction with the hydrothermal constitution of an environment. Dissatisfaction may be caused by warm or cold discomfort for the body as a whole as expressed by the PMV (Predicted Mean Vote) or PPD (Predicted Percentage Dissatisfied) indices. But hydrothermal dissatisfaction may also be caused by unwanted heating or cooling of one particular part of the body (local discomfort, more exactly nonuniformity of the hydrothermal environment).

Due to individual differences it is impossible to specify a hydrothermal environment that will satisfy everybody. There will be always a percentage of dissatisfied occupants. According to ISO 7730 recommended comfort requirements are specified that are known to be acceptable for at least $80 \%$ of the occupants.

\subsubsection{Light, mainly sedentary activity during winter conditions (heating period)}

Clothing of $1 \mathrm{clo}=0.155 \mathrm{~m}^{2} \cdot{ }^{\circ} \mathrm{C} / \mathrm{W}$ is assumed. The conditions are the following:

a) The operative temperature shall be between 20 and $24^{\circ} \mathrm{C}$ (i.e. $22 \pm 2{ }^{\circ} \mathrm{C}$ ), relative humidity about $50 \%$.

b) The vertical air temperature difference between $1.1 \mathrm{~m}$ and $0.1 \mathrm{~m}$ above the floor (head level and ankle level) shall be less than $3{ }^{\circ} \mathrm{C}$.

c) The surface temperature of the floor shall normally be between 19 and $26{ }^{\circ} \mathrm{C}$, but floor heating systems may be designed for $29^{\circ} \mathrm{C}$.

d) The mean air velocity shall be less than $0.15 \mathrm{~m} / \mathrm{s}$.

e) The radiant temperature asymmetry from windows or other cold vertical surfaces shall be less than $10^{\circ} \mathrm{C}$ (in relation to a small vertical plane $0.6 \mathrm{~m}$ above the floor).

f) The radiant temperature asymmetry from a warm (heated) ceiling shall be less than $5^{\circ} \mathrm{C}$ (in relation to a small plane $0.6 \mathrm{~m}$ above the floor).

\subsubsection{Light, mainly sedentary activity during summer conditions (cooling period)}

Clothing of $1 \mathrm{clo}=0.078 \mathrm{~m}^{2} \cdot{ }^{\circ} \mathrm{C} / \mathrm{W}$ is assumed. The conditions are the following:

a) The operative temperature shall be between 23 and $26{ }^{\circ} \mathrm{C}$ (i.e. $24.5 \pm 1.5^{\circ} \mathrm{C}$ ), relative humidity about $50 \%$.

b) The vertical air temperature difference between $1.1 \mathrm{~m}$ and $0.1 \mathrm{~m}$ above floor (head and ankle level) shall be less than $3{ }^{\circ} \mathrm{C}$.

c) The mean air velocity shall be less than $0.25 \mathrm{~m} / \mathrm{s}$.

\subsubsection{Other activities during both winter and summer conditions}

The optimum operative temperature as a function of various activities and clothing is presented in Fig. 16.

\subsubsection{Drafts}

Draft, especially cold draft, seems to be the most difficult hydrothermal comfort problem for building interiors nowadays. Thus European Standard "Ventilation of Buildings, design Criteria for the Indoor Environment" CEN/TC 156 introduces a new criterion, the so called Draft Rating (DR), which can be estimated, e.g., by SWEMA AIR 300 with an SWA 01 probe (Fig. 17). DR is defined as the percentage of persons who perceive the draft in an investigated place as 


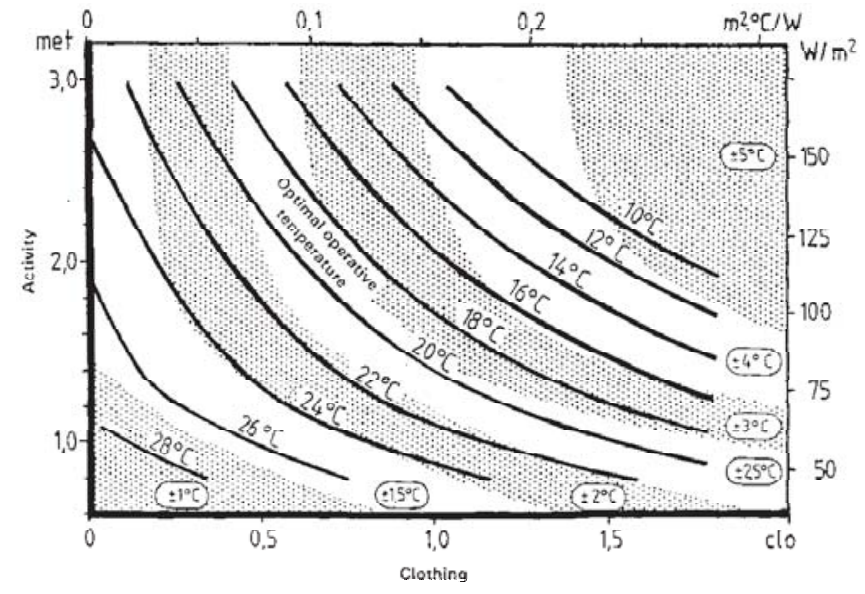

Fig. 16: The optimum operative temperature as a function of activity and clothing according to ISO 7730

dissatisfying. DR depends on air velocity, air turbulence (vortices in the air) and air temperature.

\subsection{A new standard based on space research}

A new standard for optimum hydrothermal environment conditions (hydrothermal constituent of the microenvironment) based on Soviet space research findings has been introduced in Prague, Czech Republic. Class One (see Table 6) of this standard with a total metabolic rate up to $80 \mathrm{~W} / \mathrm{m}^{2}$ can be applied to a residential environment. The optimum operative temperature range is based partly on temperatures just before the onset of sweating (upper limit), and partly on temperatures just before the onset of shivering (lower limit) [6], [16], [17]. In addition to optimum values, admissible values are also introduced.

The nonuniformity solution arouses great interest. It seems that in both the U.S. and the European standards, the problem of moderate heat stress non-uniformity is not resolved in a proper way. First, radiant nonuniformity, known adiant asymmetry (Fig. 11), should be evaluated on the basis of human physiology. The human body is able to tolerate even high thermal radiation in cool streaming air, but only very low thermal radiation in hot streaming air, i.e., thermal radiation and convection must be taken into account simultaneously. Second, the physiological Radiant Comfort Coefficient must also be taken into account (see section 2.1).

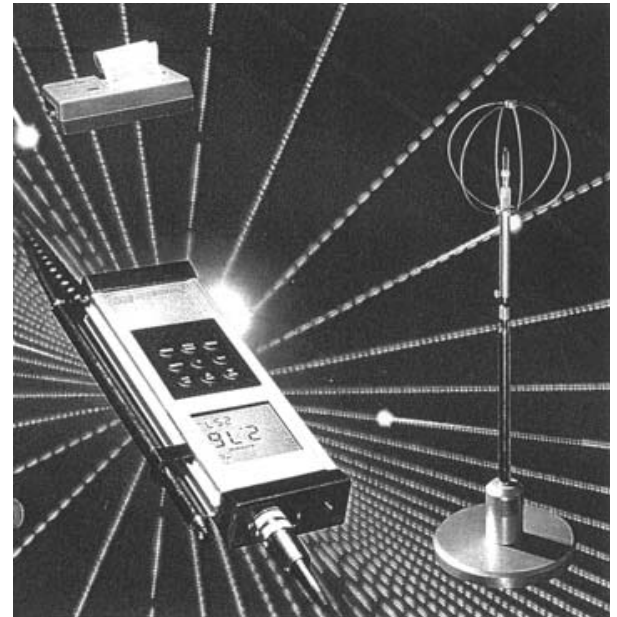

Fig. 17: SWEMA AIR 300 with the SWA 01 probe for Draft Rate estimation

Radiant asymmetry must be evaluated from the physiological point of view, simultaneously with the cooling effect of the surrounding air. In a uniform environment this fact is respected by the globe temperature or more exactly, by an operative temperature (the globe temperature is the temperature of a globe resulting from warming by radiation and cooling by convection). In a non-uniform environment this fact is respected by the stereotemperature, which is the temperature of only a part of the measuring globe, changed from the technical point of view into a so-called stereothermometer (Fig. 18). Thus thermal asymmetry can be expressed exactly as the difference of two stereotemperatures: as the radiating side minus the side without the investigated radiation [7], [8], [9], [11], [12]. For optimum and admissible values, see Table 6. If this new criterion is applied, e.g., in a living room, it is evident that the heating body, as a source of radiant heat, must be located under the window, i.e., close to the source of radiant cold (see Part 2, section 1.2.1).

As presented above, thermal comfort depends not only on the heat equilibrium of the human body, but also on the way in which it was reached, i.e., on the proportion of individual heat flows, expressed by the Radiant Comfort Coefficient (see section 2.1). From the limit value of RCC we get, for example, the maximum difference between the air temperature and the surface indoor wall temperature, e.g., $2 \mathrm{~K}$ for a man sitting and watching a TV. Of course, some further optimum and admissible values are introduced in this new standard,

Table 6: The range of optimum and admissible hydrothermal parameters for the interiors of buildings, prescribed in the Czech Republic (Work class I) (for RCC = 1)

\begin{tabular}{|l|c|c|c|c|c|c|}
\hline \multicolumn{7}{|c|}{ Cold period of the year } \\
\hline Parameters & $\begin{array}{c}\mathrm{T}_{0} \text { operative } \\
\text { temperature }\left[{ }^{\circ} \mathrm{C}\right]\end{array}$ & $\begin{array}{c}\text { Air velocity } \\
{[\mathrm{m} / \mathrm{s}]}\end{array}$ & $\begin{array}{c}\mathrm{T}_{0, \text { ankles }}-\mathrm{T}_{0, \text { head }} \\
{[\mathrm{K}]}\end{array}$ & $\begin{array}{c}\mathrm{T}_{\text {air }}-\mathrm{T}_{\text {globe }} \\
{[\mathrm{K}]}\end{array}$ & $\begin{array}{c}\mathrm{T}_{\text {air }}-\mathrm{T}_{\mathrm{g}} \text {, stereo } \\
{[\mathrm{K}]}\end{array}$ & $\begin{array}{c}\mathrm{rh} \\
{[\%]}\end{array}$ \\
\hline optimum & $20-23$ & $\leq 0.1$ & -3.0 to +9.0 & 0.4 & 1.2 & $30-70$ \\
\hline admissible & $18-24$ & $\leq 0.1$ & -4.5 to +13.4 & 0.4 & 1.2 & $30-70$ \\
\hline \multicolumn{2}{|c|}{} & \multicolumn{2}{|c|}{ Warm period of the year } & & 1.2 & $30-70$ \\
\hline optimum & $23-26$ & $0.1-0.2$ & -3.0 to +9.0 & 0.4 & 1.2 & $30-70$ \\
\hline admissible & $20-28$ & $0.1-0.2$ & -3.5 to +10.0 & 0.4 & & 1.2 \\
\hline
\end{tabular}

$\mathrm{rh}=$ relative air humidity, $\mathrm{T}_{\mathrm{g}, \text { stereo }}=$ stereotemperature measured by a stereothermometer 


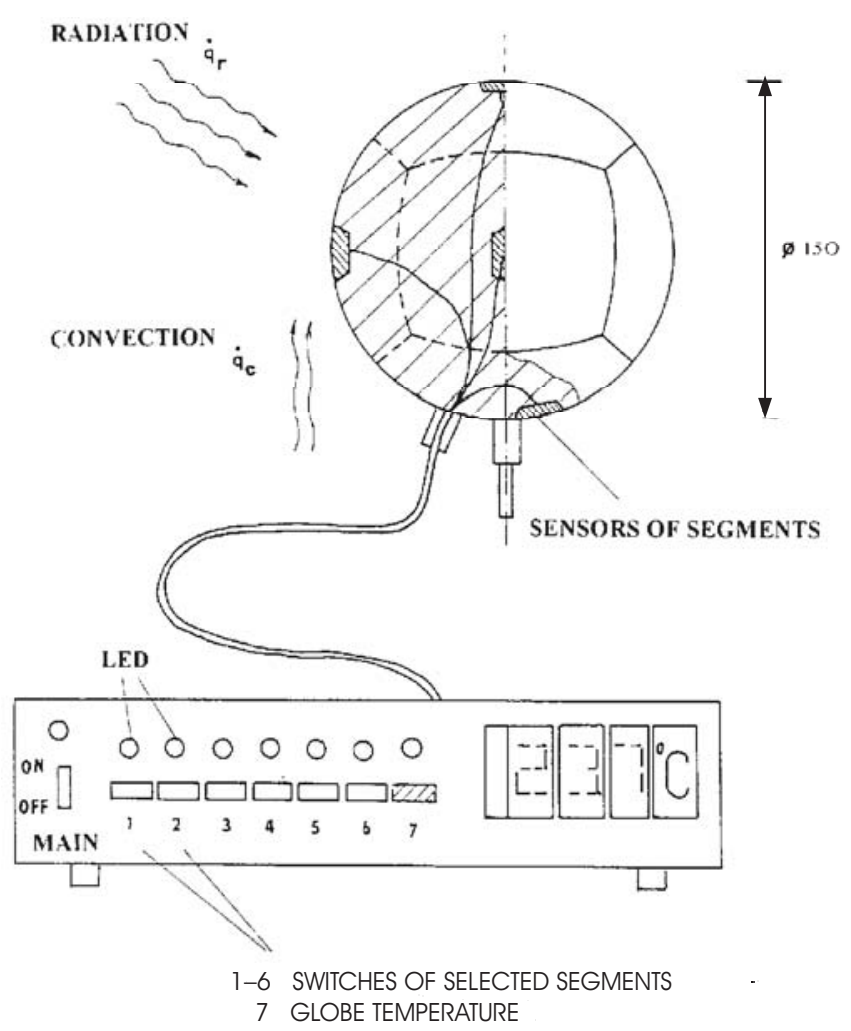

Fig. 18: Stereothermometer

e.g., an operative temperature decrease from head level to ankle level of $-3{ }^{\circ} \mathrm{C}$ and an operative temperature increase of $+9{ }^{\circ} \mathrm{C}$.

To be continued.

\section{References}

[1] Centnerová, L.: Ventilation of a family house. Topenářství, instalace, No. 3/1999, pp. 64-65

[2] Chlum, M., Jokl, M., Papež, K.: Progressive ways of residential ventilation. Společnost pro techniku prostředí, Praha 1999, pp. 75

[3] Gullev, G.: Allergy and indoor air climate. SCANVAC 1999, No. 1/1999, pp. 8-9

[4] Hensen, J., Kabele, K.: Application of system simulation to $W C H$ boiler selection. In: Proceedings of $5^{\text {th }}$ Int. IB PSA Conference, Prague 1997, pp. 141-147

[5] Jirák, Z., Jokl, M. V., Bajgar, P.: Long-term and short-term tolerable work-time in a hot environment: the limit values verification. Int. J. of Environmental Health Research No. 7/1997, pp. 33-46

[6] Jokl, M. V.: Microenvironment: The Theory and Practice of Indoor Climate. Thomas, Illinois, U.S.A. 1989, p. 416

[7] Jokl, M. V.: The stereothermometer: A new instrument for Hydrothermal constituent nonuniformity evaluation. ASHRAE Transactions 96, No. 3435/1990, pp. 13-15
[8] Jokl, M. V.: Stereothermometer for the evaluation of a hydrothermal microclimate within buildings. Heizung/Luftung, Klima, Haustechnik 42, No. 1/1991, pp. 27-32

[9] Jokl, M. V.: Stereothermometer an instrument for assessing the non-uniformity of the environmental hydrothermal constituent. Čs. hygiena 36, No. 1/1991, pp. 14-24

[10] Jokl, M. V.: Some new trends in power conservation by thermal insulating properties of buildings. Acta Polytechnica, No. 8/1990, pp. 49-63

[11] Jokl, M. V.: Hydrothermal microclimate: A new system for evaluation of non-uniformity. Building Serv. Eng. Technol. 13, No. 4/1992, pp. 225-230

[12] Jokl, M. V.: Theory of the non-uniformity of the environment at hydrothermal constituent. Stavební obzor 1, No. 4/1992, pp. 16-19

[13] Jokl, M. V.: Internal Microclimate. Czech Technical University in Prague, Prague 1992, p. 182

[14] Jokl, M. V.: The Theory of the Indoor Environment of a Building. Czech Technical University in Prague, Prague 1993, p. 261

[15] Jokl, M. V.: Energetics of Building Environsystems. Czech Technical University in Prague, Prague 1993, p. 148

[16] Jokl, M. V., Moos, P.: Optimal globe temperature respecting human thermoregulatory range. ASHRAE Transactions 95, No. 3288/1989, pp. 329-335

[17] Jokl, M. V., Moos, P.: The nonlinear solution of the thermal interaction of the human body with its environment. Technical Papers, TU Prague, Building Construction Series, PS No. 6/1992, pp. 15-24

[18] Kabele, K., Kadlecová, M., Matoušovic, T., Centnerová, L.: Application of complex energy simulation in competition design of the Czech embassy in Ottawa. In: Proceedings of $6^{\text {th }}$ Int. IBPSA Conference, Kyoto, Japan 1999, pp. 249-255

[19] Kadlecová, M.: Internal microclimate in museums, galeries and exhibition rooms. Dissertation, Czech Technical University in Prague, Prague 1992, pp. 47

[20] Kopřiva, M.: Buildings saving energy. Topenářství, instalace 33, No. 5/1999, pp. 98-99

[21] LUNOS Luftungsfibel. Berlin 1999, pp. 21

[21] Papež, K.: Ventilation and Air Conditioning - exercises. Czech Technical University in Prague, Prague 1993, pp. 116

[22] Sandberg, M.: Hybrid ventilation, new word, new approach. Swedish Building Research, No. 4/1999, pp. 2-3

Miloslav V. Jokl, Ph.D., Sc.D, University Professor phone: +420224354432

fax: +420233339961

e-mail: miloslav.jokl@fsv.cvut.cz

Czech Technical University in Prague

Faculty of Civil Engineering

Thákurova 7

16629 Prague 6, Czech Republic 